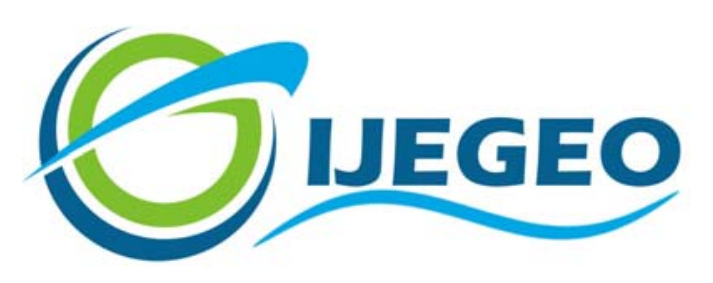

International Journal of Environment and Geoinformatics (IJEGEO) is an international, multidisciplinary, peer reviewed, open access journal.

\title{
The Effect of UAV Usage on Detail Points in Cadastre Update Studies: Çorum-Karaköy Case Study
}

\section{Kamil KARATAŞ, Nurgül Seher ALTINIŞIK}

\author{
Chief in Editor \\ Prof. Dr. Cem Gazioğlu \\ Co-Editors \\ Prof. Dr. Dursun Zafer Şeker, Prof. Dr. Şinasi Kaya, \\ Prof. Dr. Ayşegül Tanık and Assist. Prof. Dr. Volkan Demir
}

Editorial Committee (August 2020)

Assos. Prof. Dr. Abdullah Aksu (TR), Assit. Prof. Dr. Uğur Algancı (TR), Prof. Dr. Bedri Alpar (TR), Prof. Dr. Lale Balas (TR), Prof. Dr. Levent Bat (TR), Prof. Dr. Paul Bates (UK), İrşad Bayırhan (TR), Prof. Dr. Bülent Bayram (TR), Prof. Dr. Luis M. Botana (ES), Assos. Prof. Dr. Gürcan Büyüksalih (TR), Prof. Dr. Nuray Çağlar (TR), Prof. Dr. Sukanta Dash (IN), Dr. Soofia T. Elias (UK), Prof. Dr. A. Evren Erginal (TR), Assoc. Prof. Dr. Cüneyt Erenoğlu (TR), Dr. Dieter Fritsch (DE), Prof. Dr. Çiğdem Göksel (TR), Prof.Dr. Lena Halounova (CZ), Prof. Dr. Manik Kalubarme (IN), Dr. Hakan Kaya (TR), Assist. Prof. Dr. Serkan Kükrer (TR), Assoc. Prof. Dr. Maged Marghany (MY), Prof. Dr. Michael Meadows (ZA), Prof. Dr. Nebiye Musaoğlu (TR), Prof. Dr. Masafumi Nakagawa (JP), Prof. Dr. Hasan Özdemir (TR), Prof. Dr. Chryssy Potsiou (GR), Prof. Dr. Erol Sarı (TR), Prof. Dr. Maria Paradiso (IT), Prof. Dr. Petros Patias (GR), Prof. Dr. Elif Sertel (TR), Prof. Dr. Nüket Sivri (TR), Prof. Dr. Füsun Balık Şanlı (TR), Prof. Dr. Uğur Şanlı (TR), Duygu Ülker (TR), Prof. Dr. Seyfettin Taş (TR), Assoc. Prof. Dr. Ömer Suat Taşkın (US), Dr. İnese Varna (LV), Dr. Petra Visser (NL), Prof. Dr. Selma Ünlü (TR), Assoc. Prof. Dr. İ. Noyan Y1lmaz (AU), Prof. Dr. Murat Yakar (TR), Assit. Prof. Dr. Sibel Zeki (TR)

Abstracting and Indexing: TR DIZIN, DOAJ, Index Copernicus, OAJI, Scientific Indexing Services, International Scientific Indexing, Journal Factor, Google Scholar, Ulrich's Periodicals Directory, WorldCat, DRJI, ResearchBib, SOBIAD 


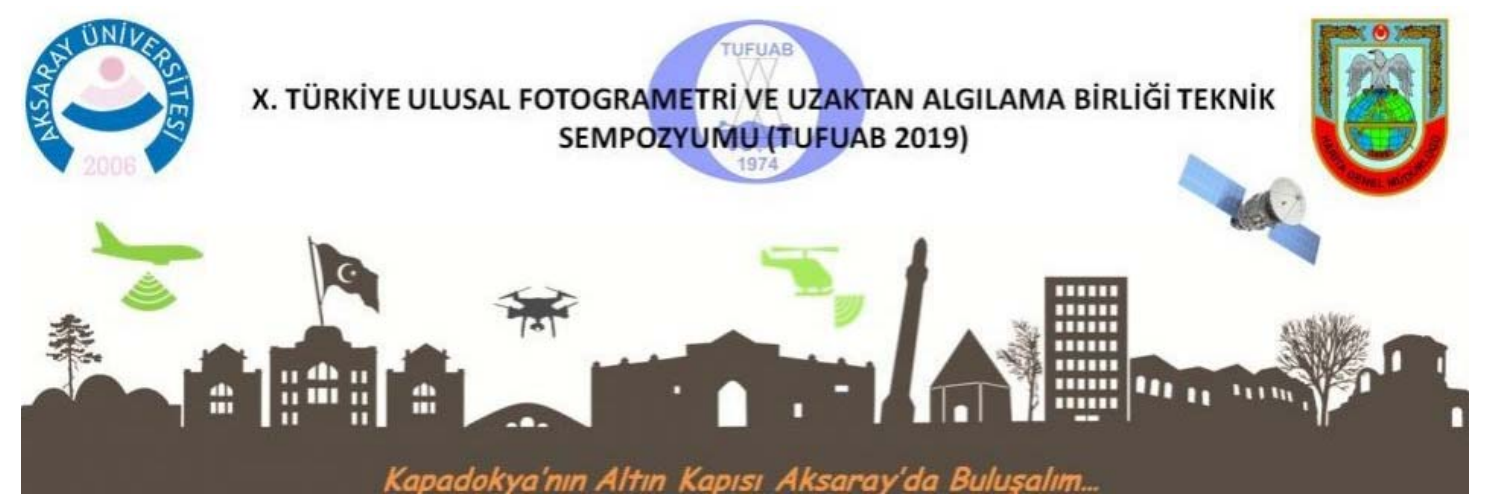

Dear colleagues and friends,

X. TUFUAB Technical Symposium was held in Aksaray on 25-27, April 2019. The Symposium was carried out by the organizations of Aksaray University and General Directorate of Mapping. As a international symposium in the field of photogrammetry and remote sensing, X.TUFUAB Technical Symposium 2019 is devoted to promote the advancement of knowledge, research, development, education and training in Geographical Information Sciences, Information Technology, Environmental Management and Resources, Sustainable Agriculture, Surveying, Photogrammetry and Remote Sensing, their integration and applications, as to contribute to the well-being of humanity and the sustainability of the environment. 425 participants and scientists from 7 countries were attended to this symposium. 125 oral presentations and 10 poster presentations were presented during the symposium. 135 presentations take place in 25 sessions in two days.

The presentations were reviewed by the scientific committee. Nine of these presentations were found worthy to be published in "International Journal of Environment and Geoinformatics (IJEGEO)" by the scientific committee. We would like to thank editorial board of IJEGEO for the publication of these works in the symposium.

Aksaray, Turkey, April 2019.

Prof. Dr. H. Murat YILMAZ

Dr. Eng. Tuğg. Oman ALP

Chair of the Organizing Committee

Director, General Directorate of Mapping 


\title{
The Effect of UAV Usage on Detail Points in Cadastre Update Studies: Çorum- Karaköy Case Study
}

\author{
Kamil Karataş $^{1 *}$, ID Nurgül Seher Altınışık ${ }^{2}$ iD \\ ${ }^{1}$ Aksaray Üniversity, Faculty of Engineering, Aksaray-TR \\ ${ }^{2}$ Asbey Map İmar Trade. Co. Ltd., Survey Engineer, Ankara-TR \\ * Corresponding author:K. Karataş \\ E-mail: kkaratas42@gmail.com
}

Received 13 Nov 2019

Accepted 19 April 2020

How to cite: Karataş and Altııı̧ı (2020). The Effect of UAV Usage On Detail Points in Cadastre Update Studies: Çorum-Karaköy Case Study, International Journal of Environment and Geoinformatics (IJEGEO), 7(2), 140-146. DOI: 10.30897/ijegeo.646155

\begin{abstract}
In Turkey, cadastral studies to determine the position, areas, and legal status of the real estate parcels have been carried out for a period of approximately 100 years by various laws, measurement methods, measurement instruments, and substrates. In Turkey, it is necessary to update $40 \%$ of the existing parcels because of problems such as produced cadastral substrates that do not reflect the ground structure, inadequate standards for technical reasons, and insufficient spatial data for the establishment of systems. The technical part of the studies for the cadastral update is carried out by the use of modern measurement methods and advanced technological devices, with the contribution of the private sector by the tender procedure. The unmanned aerial vehicle (UAV), which is one of the technological devices, can provide three-dimensional appearance and accuracy, the ability to interpret the land, and time reduction in the studies for cadastral updates. In this study, the contribution of data obtained by a UAV to the detailed studies was investigated for 56 parcels on a cadastral island that has an area of 24.71 ha for the renewal of cadastral parcels related to Karaköy Village of Çorum Province, Osmancık District. The number of detail points determined by the classical method was 392 , while the number of detail points determined by the UAV was 682 .
\end{abstract}

Keywords: Cadastre, Cadastre Update, UAV, Detail points

\section{Introduction}

In Turkey, the cadastral works carried out to determine the positions, geometric structures, fields, and legal status of real estate have been completed, except for a few units, over a period of 100 years. During that process, various measurement methods, measurement tools, and scales or coordinate systems have been used on substrates, depending on technological developments, economic situations and legislative changes (Figure 1).

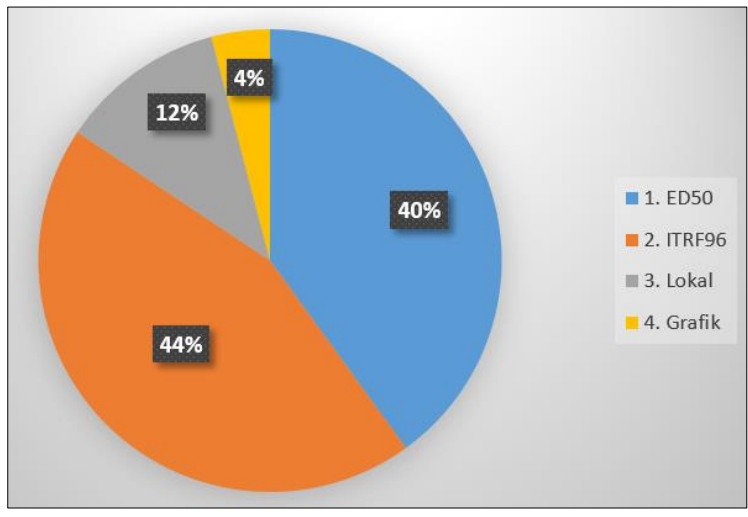

Fig. 1. Coordinate systems used in cadastral works.

This situation has led to the development of errors in the cadastral works, changes in the standards of data production over time, the inability to meet increasing needs with the developing technology, and failure to create the base of a spatial information system. Various steps have been taken to update the cadastre to meet expectations.

Technical, legal, and administrative changes have been made regarding the cadastral update. The first legal arrangement, Law No. 2859 on the "Renewal of Land Registry and Cadastral Layers" (RG: 25.06.1983/18088), was issued, with that arrangement allowing for the renewal of cadastral layouts. After Law No. 2859, Article 22 of Cadastre Law No. 3402 was amended in 2005, and an amendment was made to renew the cadastral maps and to provide the necessary corrections to the land registry. For the studies to be carried out according to the legal regulation in article 3402/22.a, the "Regulation on the Procedures and Principles to be followed for the Reconstruction of Cadastre Maps and Making Corrections Required in the Land Registry" was established.

A number of innovations were made In that regulation to eliminate some of the deficiencies that have occurred over time and to extend the scope, with the amendment published in the Official Gazette, dated October 25, 2018, and numbered 30576. The name of the regulation was changed by that arrangement to the "Cadastral Update Regulation." 
According to cadastre law 3402/22.a and the Cadastral Update Regulation, in Turkey, land registration, cadastre, or changes related to transactions can be done to eliminate errors caused by limitations, measurements, drawings, and calculations, such as:

- Applications without qualifications

- Inadequate technical reasons

- Transactions with detected deficiencies

- Incompatibility of cadastral plans with the base boundaries of the parcel

To update the cadastral maps of the existing cadastral parcels and to provide the necessary corrections in the land registry, transactions can be carried out in places where there is a deed and a cadastral view. In Turkey, according to the data received from the General Directorate of Land Registry and Cadastre (GDLRC) in January 2019; over 40 percent of the current $57,675,367$ cadastral parcels need to be updated in the upcoming period (Table 1).

Table 1. Number of parcels to have cadastral data updated

\begin{tabular}{lrr} 
& $\begin{array}{c}\text { Number of } \\
\text { parcels }\end{array}$ & $\begin{array}{r}\text { Percent } \\
\text { of total }\end{array}$ \\
\hline $\begin{array}{l}\text { Update related to } \\
\text { 3402/22.a }\end{array}$ & 13747229 & 23.84 \\
$\begin{array}{l}\text { Update related to } \\
\text { 3402/Annex-1 } \\
\text { TOTAL }\end{array}$ & 1025540 & 17.78 \\
& $\mathbf{1 4 7 7 2 7 6 9}$ & $\mathbf{4 1 . 6 2}$
\end{tabular}

Classical, photogrammetric, electronic total station, GNSS, and similar measurement methods and instruments/devices have been used in cadastre studies. In cadastral update studies, electronic ground measuring devices and GNSS measurement methods and devices that are based on direct land measurement are generally used. Because of the rapidly developing technology for cadastral update works, photogrammetric techniques now can be used as an alternative to the direct land measurement method, due to reasons such as location accuracy, sensitivity, and rapid data production.

Photogrammetric techniques with the use of UAVs, one of today's advanced technologies, have given a new impetus to 3D modeling (Yakar et al., 2015). UAVs are unmanned and re-usable motorized airplanes that perform specific tasks within a certain period of time, with various loads, in or outside the atmosphere. Depending on the work being carried out, their operation can be semi-automatic, automatic, or a combination of those (Blyenburgh, 1999).

Today, UAVs are used in the studies of scientific land monitoring, geological research, landslide forecasting, weather forecasting, atmospheric research, exploration and surveillance, natural disaster monitoring, surveillance, crop and human monitoring, monitoring of high-voltage lines, and archaeological site investigation. In addition, they can be used for mapping the earth and for three-dimensional city and land modeling in cadastral studies (Saripalli et al., 2003; Gazioğlu et al., 2017; Bayırhan and Gazioğlu, 2019).

Şahin ve Yakar (2007) In the accuracy of the orthophoto, the production method of the Digital Elevation Model tested the effects of grid spacing and input data. Sar1 (2007) Foresees that cadastre renewal works should be expanded and updated in scope and content. Uçakcioğlu (2008) It was found that the cadastral measurement values at fixed boundaries in the field do not match with the digitization of the layouts and the values calculated from the takeometric measurement report card.

Nacar (2015) cadastral renewal studies, aerial photography and high resolution satellite images obtained orthophoto images can be used. Pelegrina vd., (2016) The orthophotos obtained from the processing of VANT images analyzed the availability of resources for the production of current cadastral information. Mirdan ve Yakar (2017) With AgisoftPhotoScan software, the photos taken with the help of UAV and the photos taken with the help of digital camera from the ground were combined to obtain a threedimensional model and orthophoto of the workspace. Atak (2018) 3402 / 22.a stated that the data obtained by the UAV can be applied instead of terrestrial measurement at the fixed boundaries existing at the property boundary. Yücel (2018) "Second Cadastre" view of the project.

Erenoğlu ve Erenoğlu (2018) The RTK-GNSS measurement results were compared with the Digital Altitude Model, which was obtained from different date flight data and reflected the topography of an active landslide zone. Lee vd., (2019) In the study area where the river is located, the geographical information obtained, planning, flood and so on. conducting river management has analyzed with UAV.

In this study, the points of detail in cadastral updating studies were made with classical measurement method and data obtained from UAV. Cadastral block and parcel based detail point differences were obtained with these two methods and their statistical results were analyzed. The data obtained from the UAV can be underlined in the cadastral update studies due to the fact that the missing points in the detail points are minimized.

\section{Study area}

The province of Çorum, Osmancık District, Karaköy Village was selected for this study (Figure 2). Google Earth image of Karaköy Village is displayed (Figure 3).

The application area is approximately 137.7 ha in area. Almost all the agricultural areas in the study region are farm land with paddy cultivation (Figure 4). 


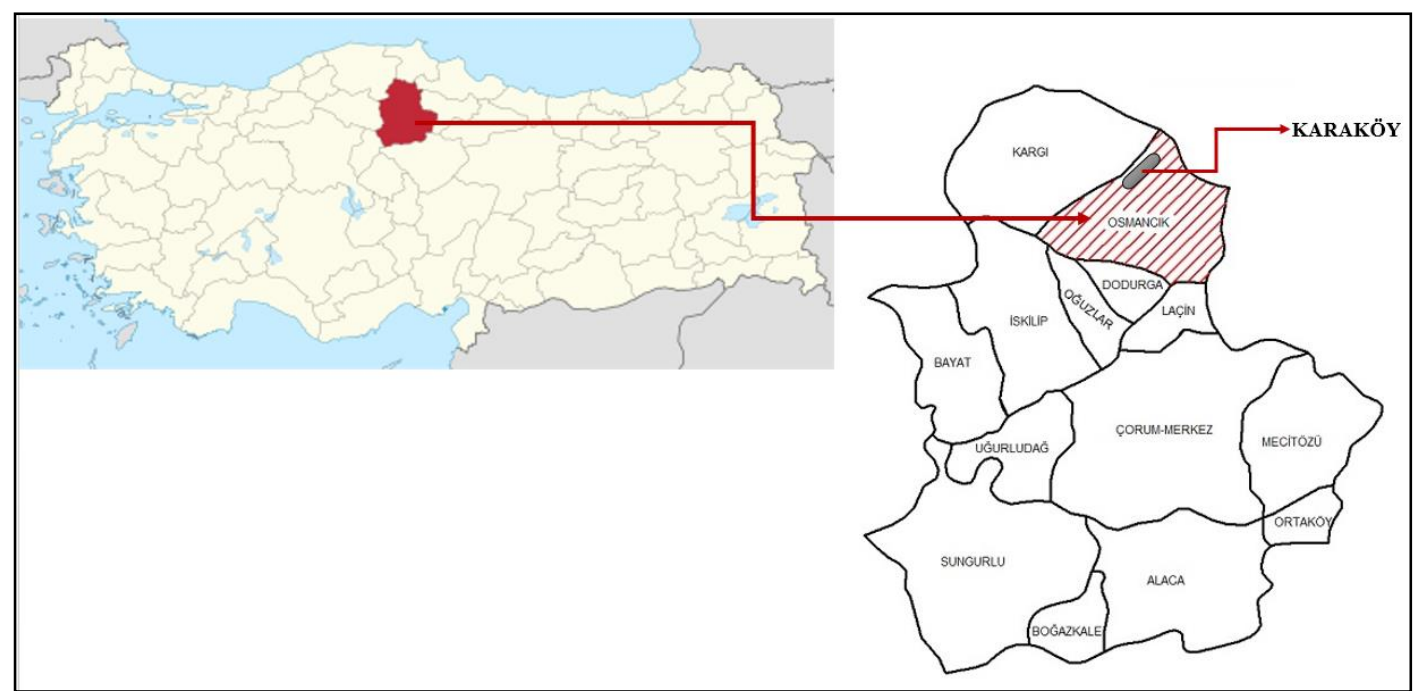

Fig. 2. Study area.

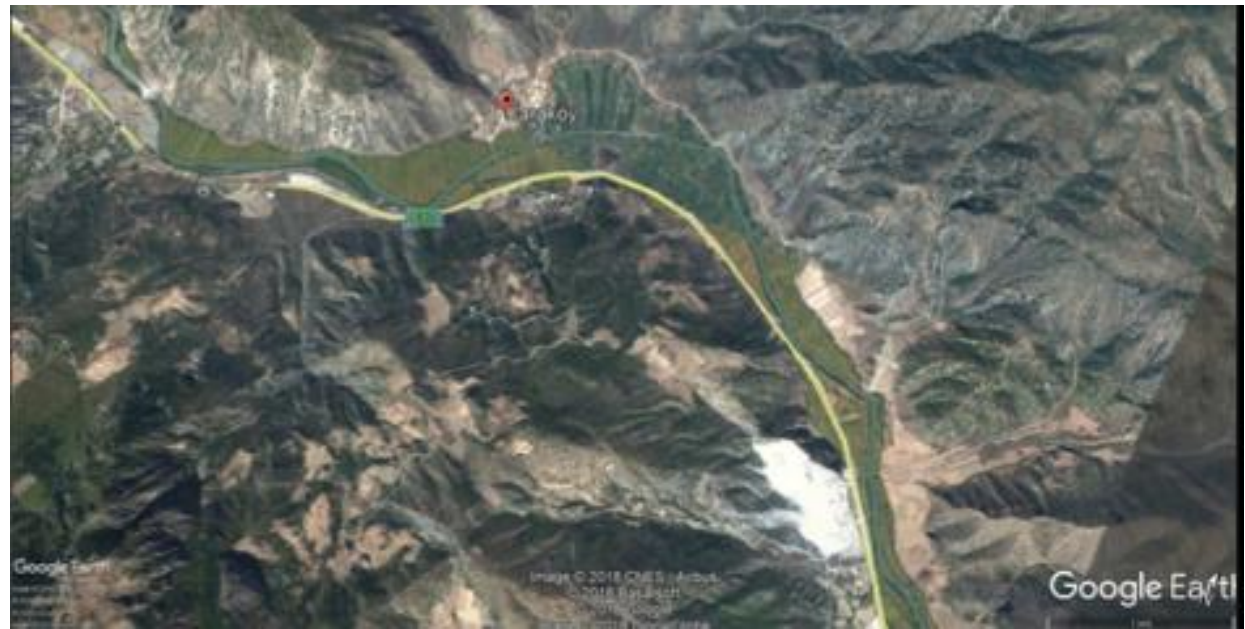

Fig. 3. Study area.

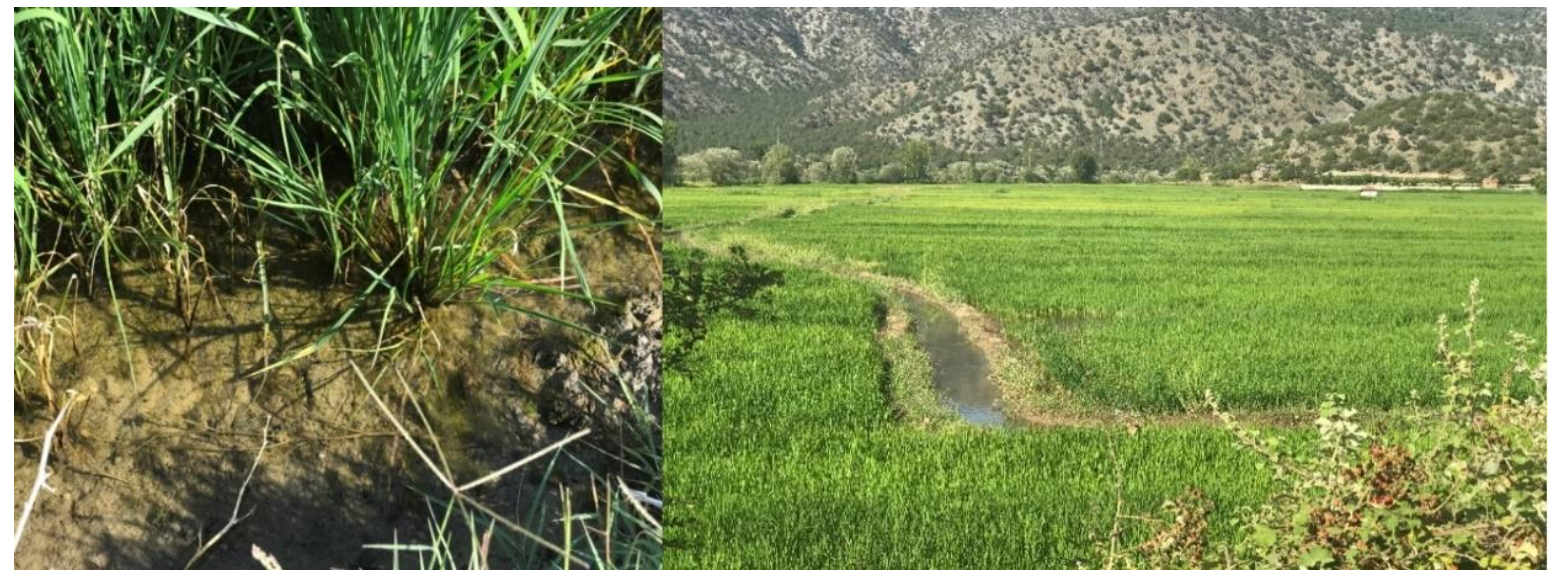

Fig. 4. View of land with paddy cultivation.

\section{Materials and methods}

The detail points in delineating the boundaries and the geometrical structure of the parcels are of great importance, both technically and legally. Otherwise, boundaries formed by detail points that are not clearly determined or incomplete lead to geometric structures of parcels that do not fully correspond to the correct surface areas. That may lead to generation of technical, legal, and social problems. The most important aspect of the cadastral update work is the determination of the detail points that make up the parcel boundaries.

The use of UAV photogrammetry, which is one of the advanced photogrammetric production methods, was investigated for the determination of the detail points forming parcel boundaries. Thus, comparison of the 
detail points determined by the evaluation of the stereo model produced from the images obtained from the UAV and the direct field measurement could be done. Within the scope of the study, Spectra Precision SP60 and SP80 GNSS devices were used for direct field measurements in the application area. The determination of the detail points in the field was done by two teams over five days.

SenseFly eBee brand UAV, senseFly 20-MP resolution S.O.D.A. digital camera (Figure 5), and Topcon GR-3 GPS devices were used to obtain images in the project work. Flight planning was prepared with the eMotion 3 program (Figure 6).

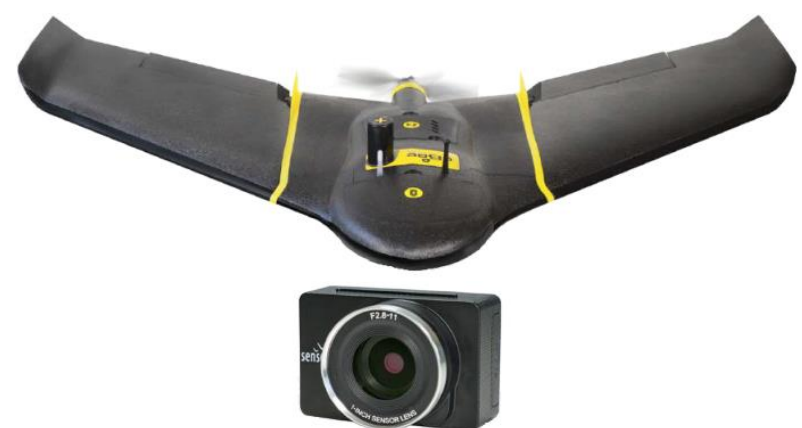

Fig.5. SenseFly eBee brand UAV and S.O.D.A. digital camera.

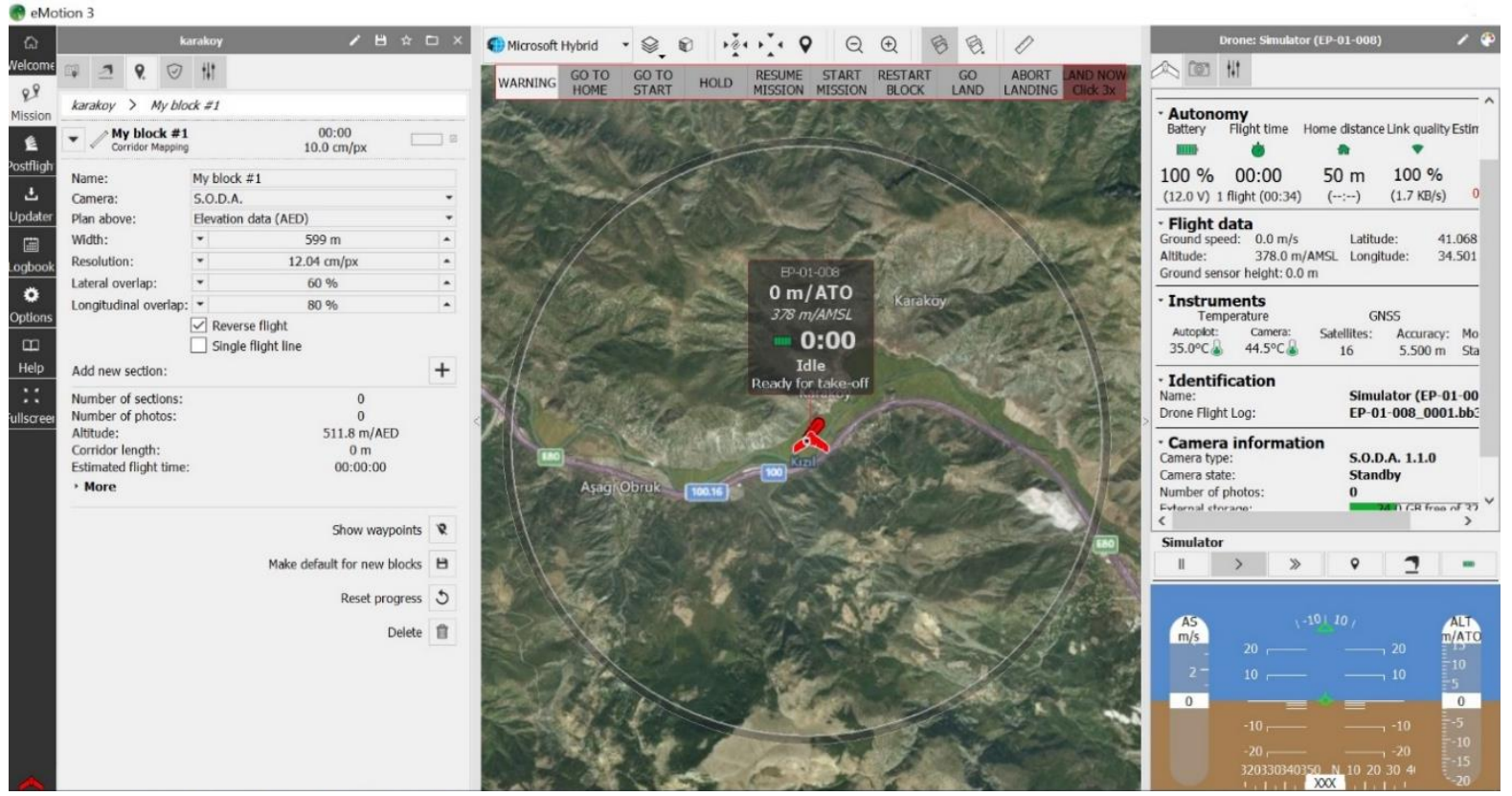

Fig. 6. Flight planning overview from eMotion 3 program.

The flight plan was prepared according to the program settings for $60 \%$ transverse and $80 \%$ overlap. At the end of the flight, which was completed in about 30 minutes from a flight height of $599 \mathrm{~m}, 235$ overlap images had been obtained. Images obtained within the scope of the study were evaluated by importing them into Agisoft PhotoScan software.
A digital elevation model (DEM) and an orthophoto map of the study area were produced (Figures 7 and 8). A stereo model was obtained by introducing images with camera and external orientation parameters into StereoCAD software. The evaluation of the stereo model can be seen simultaneously in the CAD drawing (Figure 9).

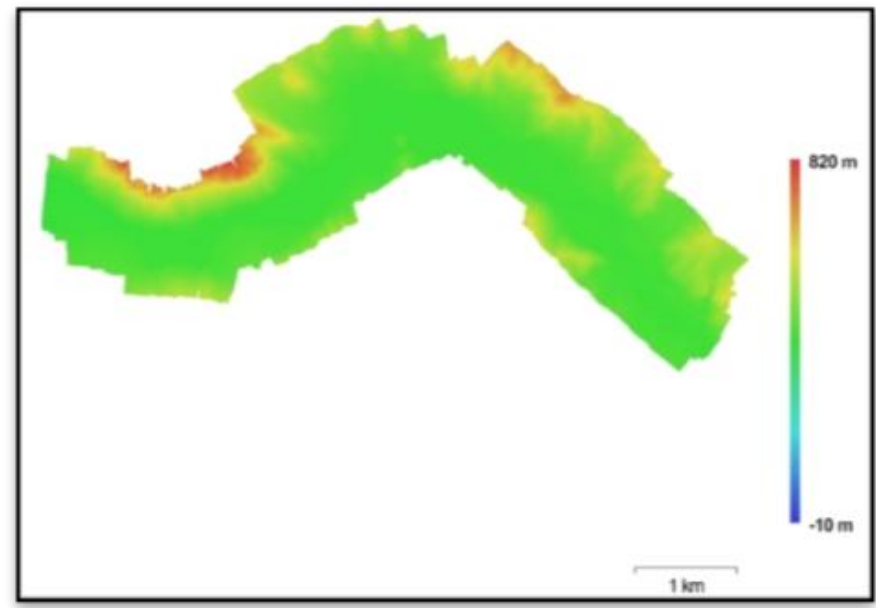

Fig. 7. Digital elevation model. 


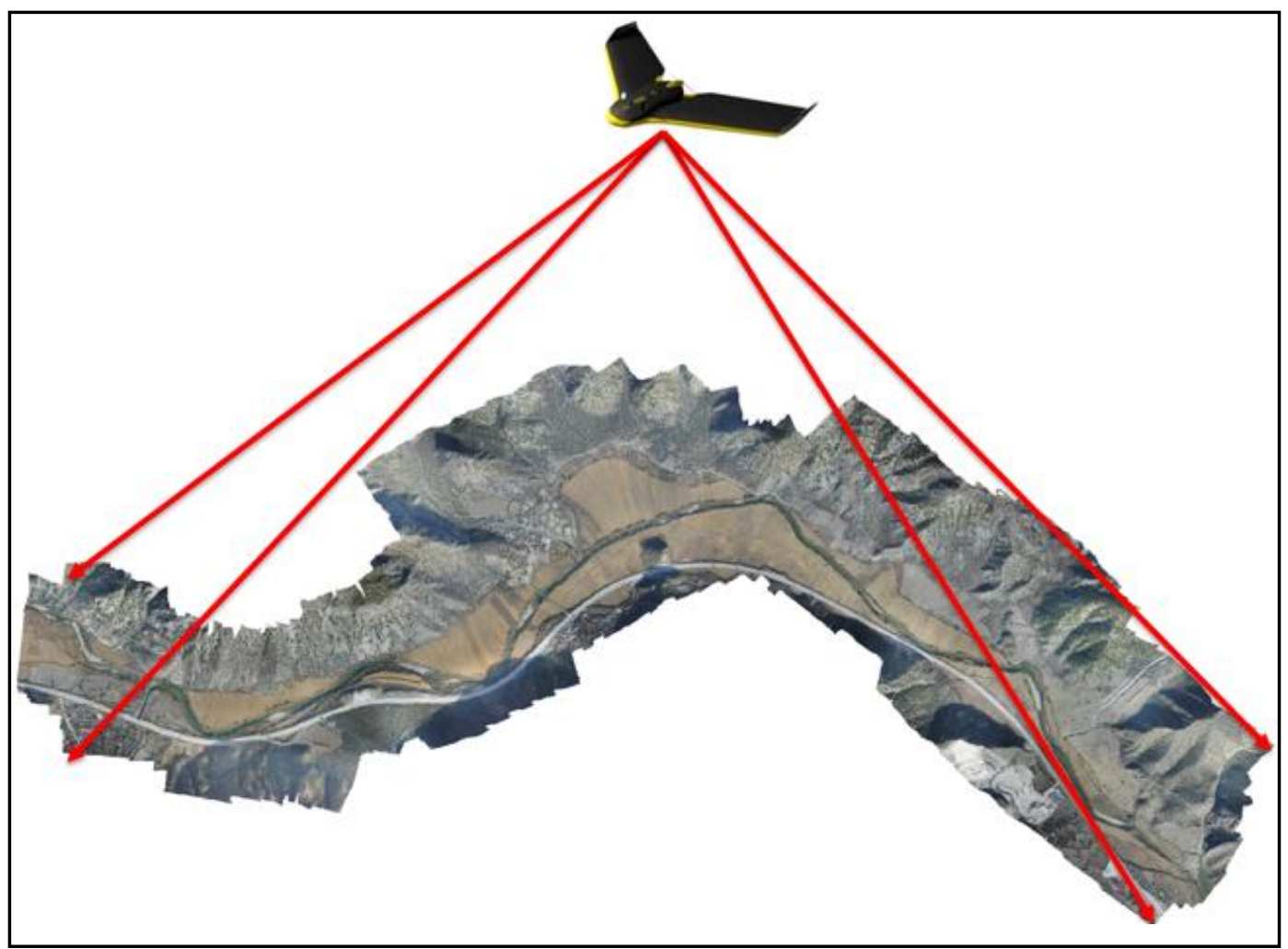

Fig. 8. Orthophoto map.

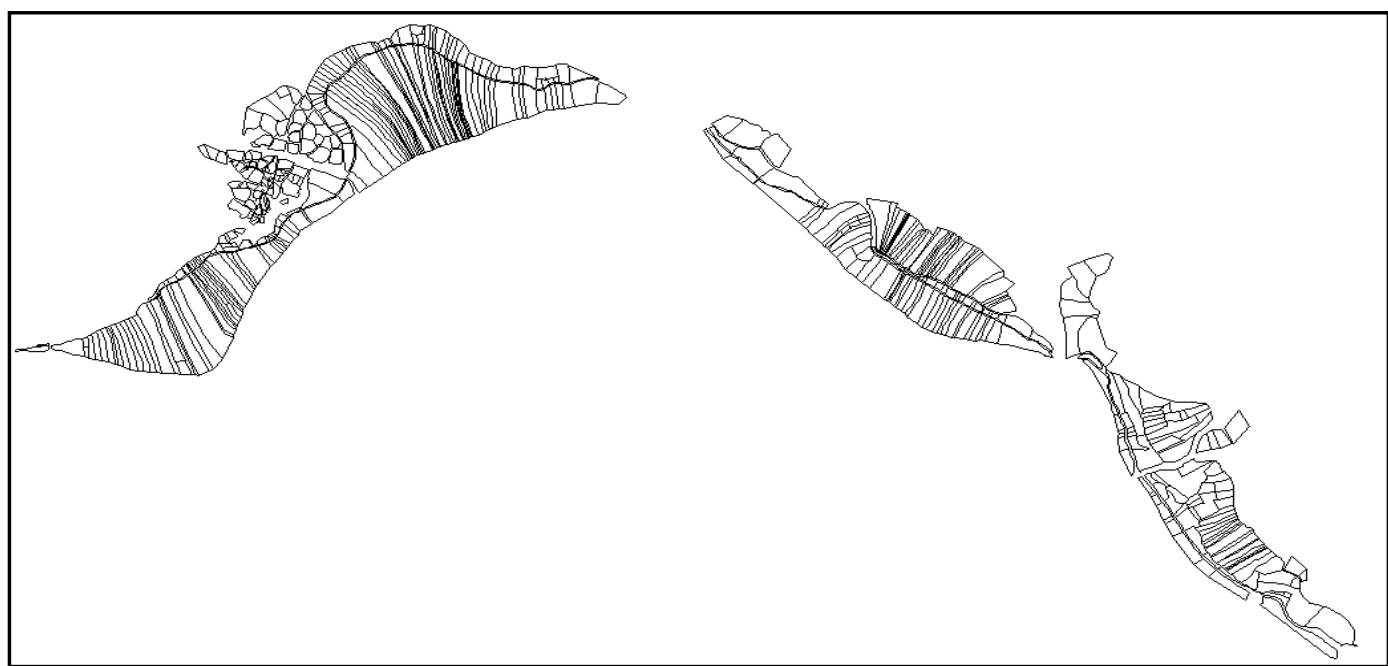

Fig. 9. Evaluation of the parcels.

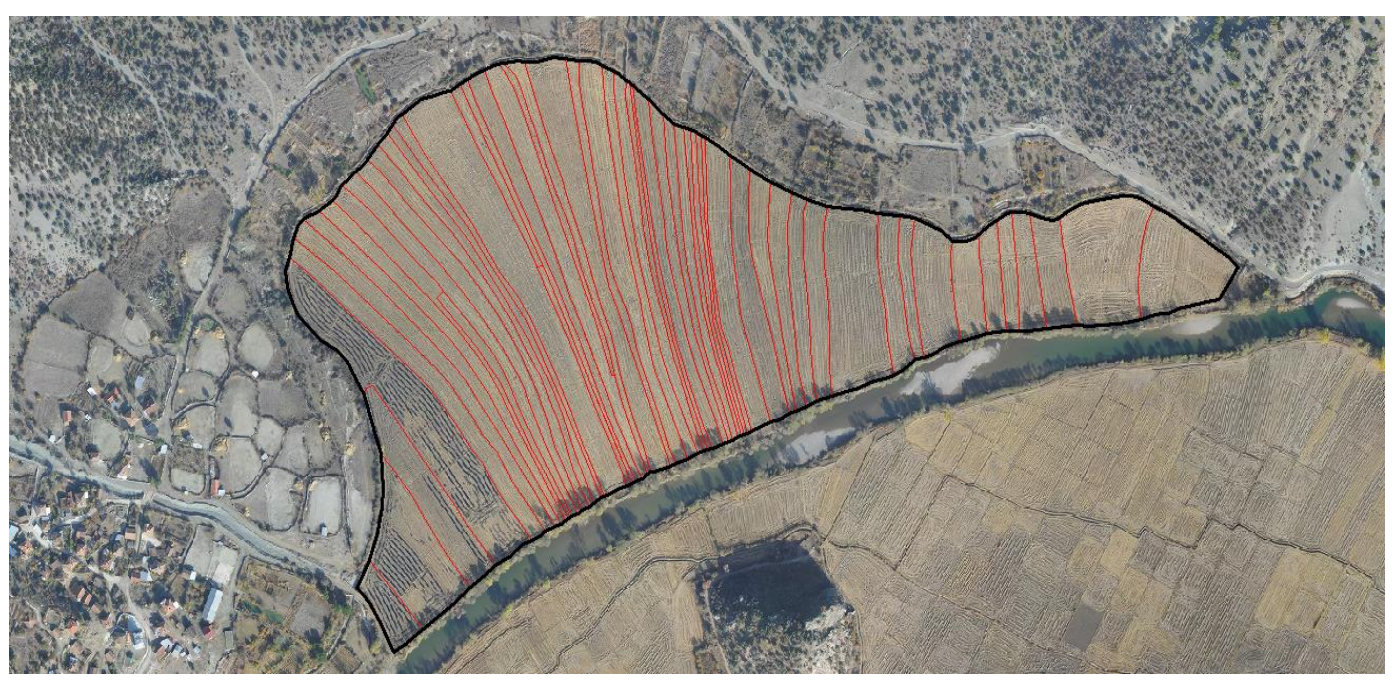

Fig. 10. Cadastral Block 152. 
In the study, a comparison was made between direct land measurements on the 56 parcels of the 24.71-hectare area on cadastral block 152 and the detail points determined from the stereo model obtained by the UAV (Figure 10).

Direct land measurements accounted for 392 detail points, while 682 detail points were determined from the

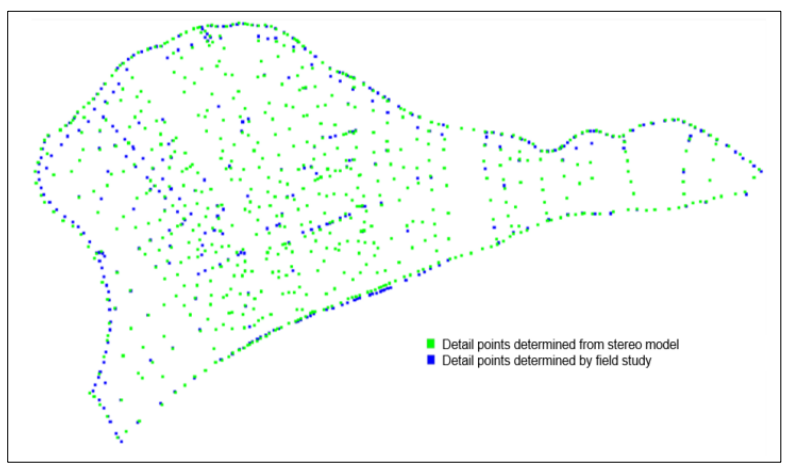

Fig. 11. Number of detail points used in the comparison

\section{Results}

On comparing the number of detail points determined by working in the field directly relative to the number of detail points determined from the stereo model, it is seen that, in 52 of the 56 parcels, the number of detail points forming the parcel boundaries determined by the stereo model is greater by a margin of 1 to 24 points than the number determined by direct measurement. In 4 of the 56 parcels, the number of detail points determined directly from land measurement is more than the detail points determined from the stereo model.

When this situation is examined, it is seen that in 1 of the 4 parcels, the same detail in the parcel is determined more than once on different days. In 3 of the 4 parcels, it is understood that the border in the same direction can be determined by two detail points, but more than one detail point is determined.

\section{Discussion and Conclusion}

Various measurement methods and measurement devices are used in cadastre studies. While developing technology leads to diversification of the devices used in all areas of life, GNSS, UAV, and similar devices are implemented in the area of cadastral update studies with the changes in methods and devices. The detail points determined by the assessment of the stereo model produced from the images obtained by the UAV were directly compared to the detail points determined in the land survey. It is seen that the number of detail points determined from the stereo model on Island 152, at an area of 24.71 hectares, was $73.98 \%$ greater than the number of detail points determined by the field study. In 52 of the 56 parcels of the cadastral island, it was observed that more detail points were determined from the stereo model than from direct field measurement. stereo model generated from the images obtained by the UAV (Figure 11).

It is seen that the number of detail points determined from the stereo model is $73.98 \%$ greater than the number of detail points determined by the direct field study. A comparison of the detail points was made on a parcel basis (Figure 12).

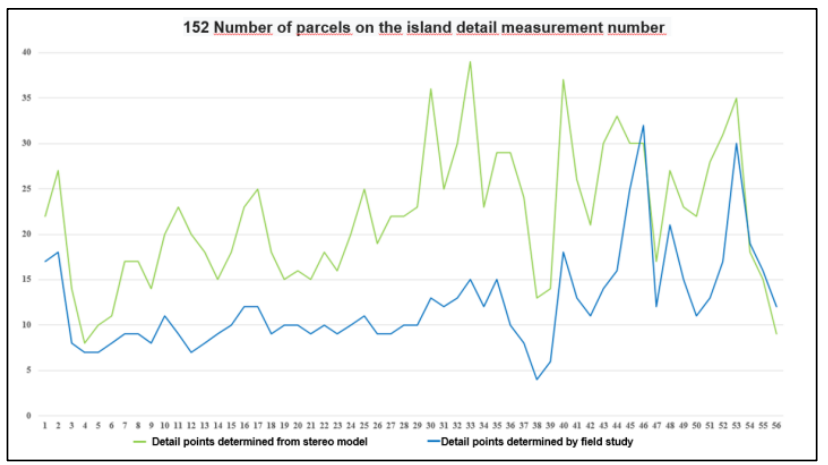

Fig. 12. Detail point comparison on parcel basis.

In four parcels, the number of detail points determined by direct field study was found to be higher than with the stereo model. In one of the four parcels, it was determined that the excess measurements were generated by duplication because the detail points were determined more than once on different days. On the other three parcels, two detail points were assigned to continuous boundaries that could have been determined with one detail point.

With the orthophoto and the 3D stereo model produced from the images obtained by the UAV, a complete visual and detailed cadastral update can be produced and perceived in the office environment without being affected by climate and terrain conditions and without the difficulties of field work. Thus, the detail points that make up the geometric shapes of the cadastral parcels were created in a more accurate, healthy, rapid, and economic way than with the direct land measurements. The use of the UAV should become more widespread to ensure consistent and accurate data on cadastral update studies because of the contributions that it has made in determining detail points.

\section{Acknowledgments}

I would like to thank following people: Survey Engineer Hakan Kürklü of the Çorum Cadastre Directorate; Survey Engineer Ismail Yelmenoğlu, the owner of ASBEY Map İmar Trade. Co. Ltd.; and Survey Engineer Ali Hararc1, the owner of the APEK Map İmar Trade. Co. Ltd.

\section{References}

Atak, B, (2018). Insansiz hava aracı yardımıla kadastral harita üretiminin incelenmesi (Y.L. Tezi). Necmettin Erbakan Üniversitesi, Konya, Türkiye.

Bayırhan, İ., Gazioğlu,C. (2019). Use of Unmanned Aerial Vehicles (UAV) and Marine Environment 
Simulator in Oil Pollution Investigations, International Symposium on Applied Geoinformatics (ISAG-2019), 1-6.

Blyenburgh Van, P. (1999). "UAVs: and Overview, In: Air \& Space Europe”, I, 5(6), 43-47.

Erenoğlu, R.C., Erenoğlu O. (2018). A case study on the comparison of terrestrial methods and unmanned aerial vehicle technique in landslide surveys: Sarıcaeli landslide, Çanakkale, NW Turkey. International Journal of -Environment and Geoinformatics (IJEGEO), 5(3), 325-336.

Gazioğlu, C., Varol, ÖE., Şeker, DZ., Çağlar, N. (2017). Determination of the Environmental Impacts of Marine Accidents Using UAV and RS Technologies, 19th MESAEP Symposium on Environmental and Health Inequity, Roma, ITALYA, 3-6 Dec 2017.

Lee, G., Choi, M., Yu, W., \& Jung, K. (2019). Creation of river terrain data using region growing method based on point cloud data from UAV photography. Quaternary International, 519(10), 255-262.

Mirdan, O., Yakar, M. (2017). Tarihi Eserlerin İnsansız Hava Aracı İle Modellenmesinde Karşılaşılan Sorunlar. Geomatik, 2(3), 118-125.

Nacar, F, (2015). Investigation of the availability of cadastral renovation work in high-resolution satellite images and orthophotos in Turkey, (PhD thesis). Selçuk Üniversitesi, Konya, Turkey.

Pelegrina, M., A Canal, M., Julião, R. P. S. P. M., Kolosinski Obal, K. (2016). Atualização cadastral dirigida, utilizando ortofotos oriundas de Vant. Actas I Seminário Internacional UAV, 129-132.

Şahin, İ., Yakar, M. (2007). Farklı Kaynaklardan Elde Edilen Sayısal Yükseklik Modellerinin Ortofoto Doğruluğuna Etkilerinin Araştırılması.

Sarı, İ, N., Demirel, Z. (2007). Ülkemiz Kadastrosunda Yenileme Olgusu ve Önerileri, Jeodezi, Jeoinformasyon ve Arazi Yönetimi Dergisi, 1(96), 1321.

Saripalli, S., Montgomery, J. F., Sukhatme, G. S. (2003). Visually Guided Landing Of An Unmanned Aerial Vehicle. Robotics and Automation, IEEE Transactions on, 19(3), 371-380.

Uçakcioğlu, E, (2008) Kadastro Paftalarının Yenilenmesi Üzerine Bir Inceleme, (Y.L. Tezi). Afyon Kocatepe Üniversitesi, Afyon, Türkiye.

Yakar, M., Toprak, A. S., Ulvi, A., Uysal, M. (2015). Konya Beyşehir Bezariye Hanının (Bedesten) İHA İle Fotogrametrik Teknik Kullanılarak Üç Boyutlu Modellenmesi. Türkiye Harita Bilimsel ve Teknik Kurultay, Ankara, Turkey.

Yücel, F, (2018) Kadastrodaki Yenileme Çalışmalarının Farkl Kadastral Teknik ve Mevzuat Uygulamalarıla Karşılaştırılarak Incelenmesi, (Y.L. Tezi). Zonguldak Bülent Ecevit Üniversitesi, Zonguldak, Türkiye. 